\title{
Youth attitudes to persons with disabilities in relation to the type of their school environment - a pilot study
}

\author{
Aleksandra Sadziak' ${ }^{1}$ Dawid Matczak², Marta Wieczorek¹ \\ 'Department of Methodology of School Physical Culture, Wroclaw University of Health and Sport Sciences, Poland \\ ${ }^{2}$ Department of Physical Education and Sports, Calisia University, Poland
}

\begin{abstract}
Objectives: This article presents the results of research aimed at determining how a particular school environment affects positive attitudes towards persons with disabilities among youth attending rural and urban schools and a school with integrated classes.

Material and methods: The research process was based on diagnostic survey and questionnaire. The research tool applied was the Scale of Attitude Towards Persons with Disabilities (PWON) by Sękowski. The study included 200 respondents aged 14 and 15 years. They were young people attending three selected primary schools: one mainstream rural school, one mainstream urban school, and one mainstream urban school with integrated classes.

Results: ANOVA showed a statistically significant effect: F $(2.198)=148.28 ; p=0.00 ; \eta^{2}=0.59$ which proves that the attitudes towards people with disabilities also depend on the type of schools attended by the compared groups. There were statistically significant differences between all compared groups of young people, out of which the respondents attending the mainstream urban school with integrated classes show the most positive attitude towards persons with disabilities.

Conclusions: Average level of positive attitude towards disabled persons in young people varies according to the type of school they attend. Based on data analysis, it was found that the type of school the investigated young people attend is a variable that significantly differentiates attitudes towards persons with disabilities.
\end{abstract}

KEY WORDS: disability, attitudes, attitudes towards persons with disabilities, education, integration.

ADDRESS FOR CORRESPONDENCE: Aleksandra Sadziak, Department of Methodology of School Physical Culture, Wroclaw University of Health and Sport Sciences, Poland, e-mail: aleksandra.sadziak@awf.wroc.pl

\section{INTRODUCTION}

The concept of "attitude" is a term focused on issues that are addressed increasingly frequently in professional literature, both in psychology and sociology [1]. In its broadest sense, it is assumed that it is an effective way of estimating the world around us [2]. The attitude may be taken towards any object, event, idea or another person and is a relatively constant tendency of people to respond positively or negatively to them. The most often mentioned four sources which justify its individual development are: acquiring beliefs about the characteristics of an attitude, emotional experiences related to a specific subject of attitude, our own behaviours directed at its subject, and adopting attitudes similar to those shown by other people [3]. There is also a specific view that attitude is a relatively stable structure, but it is acquired, developed and modified at the same time as a result of the learning process [4].

The representatives of social sciences today note that we are unable to realize many of our attitudes; we are unable to become aware of the fact that we have some attitudes. They are important, however, because they affect our behaviour and the way we build social reality [5]. Attitudes are considered to be values that 
have the power to direct, reinforce or reduce specific actions, behaviours of individuals and social groups [1], and therefore appear to be of great importance for creating interpersonal relationships and pro-social behaviours.

The problem of developing attitudes towards persons with disabilities seems interesting considering current social and political changes. It is a common claim in the literature that developing positive attitudes towards persons with disabilities is particularly important and a prerequisite for overall activities of educational institutions and opinion leaders. If these objectives are marginalized, the group of people with special needs will always be separated by psychosocial barriers from healthy people. In the absence of favourable attitudes shown by the environment, social inclusion of persons with disabilities is not possible and this is one of the main tasks of the revalidation process [6]. However, attitudes towards persons with disabilities are more likely to be negative. It is believed that this is conditional on social stereotypes, traditional prejudice or a lack of knowledge of needs, opportunities and difficulties faced by persons with disabilities. Negative attitudes are otherwise referred to as rejection attitudes and are manifested by such behaviours as indifference, emotional hostility, reluctance, isolation or even disgust [7]. Positive attitude is opposite to the one discussed above. It is characterised by acceptance of persons with disabilities and is manifested by friendliness, respect, adequate evaluation, friendly behaviour and interaction [6]. In the literature on special pedagogy, contemporary researchers are beginning to identify new opportunities to transform negative attitudes towards persons with disabilities into more desirable positive ones. The opportunity to change the still widespread state of affairs is seen in the increasingly popular integration efforts. This is seen as extending social awareness of persons with disabilities by society, increasing the frequency of contacts with them and activating the environment of persons with disabilities themselves in order to raise the social competence of this group of people so that they can become attractive and equal partners in social contacts [8]. Already in the 1990s, research [9] showed that small integration groups of children with varied physical, psychological and mental health staying together in a variety of situations are stimulating for each individual in the group. Small groups facilitate direct contact between children, while educators are also able to meet all the needs of children. In such an atmosphere, non-disabled children have the opportunity to learn naturally the right attitude towards disabled peers. Such moments spent together, filled with fun, learning, cheerful and sad times, can lead to the survival of the community, mutual trust and consequently full mutual acceptance. This mechanism is also described by Sękowski [10], who points out that attitudes towards persons with disabilities develop in a specific social environment. The research focused on this process depends on: personality traits of persons with disabilities, personality of non-disabled persons and conditions under which interactions between persons with disabilities and the non-disabled ones take place. As Sękowski points out, the integration system of education for pupils with disabilities creates new but promising conditions for developing attitudes, and even contributes to forming more appropriate attitudes, as they are the result of sound knowledge and experience, not stereotypes and prejudices. The study by Kulesza [11] focused on the perception of persons with disabilities and attitudes of non-disabled students towards their peers with disabilities. It was conducted in an unconventional manner, namely by the analysis of documents - drawings of pupils from mainstream schools and schools with integrated classes. They revealed that regardless of the type of facility most students showed willingness to interact with a person having special needs. In their drawings, pupils of mainstream schools presented a more joyful atmosphere of interactions with disabled peers. Pupils of schools with integrated classes compared to the group mentioned above had a greater knowledge of disabilities revealed by a far more varied emotional background of interactions with a clearer demonstration of empathy and presented more social behaviour towards the elderly with disabilities. Therefore, contacts with persons with disabilities that are ensured through integration education appears to be of importance. Acquisition of attitudes in such a system may determine the strength of their influence on the specific behaviour shown by individuals. This is confirmed by a series of experiments conducted by Fazio and Zanna [2]. The authors' research results showed that when attitudes are based on one's own experiences, their importance and value in regulating subsequent behaviours increase. Moreover, they are a source of motivation for people to be active and are therefore more well-considered, expressed more decisively, more resistant to attacks and made more obvious. Research is largely in favour of the benefits of integration education for persons with disabilities as well as for their non-disabled peers. However, Bełza and Prysak [12] are of a different view, noting that current educational trends, although intended to provide an opportunity to normalize the lives of persons with disabilities, are in fact further apparent actions which most often have the opposite effect. Gajdzica [13] is not uncritical of the activities carried out by schools with integrated classes and claims that setting the two groups of the non-disabled and the disabled against each other leads to undermining the position of a student with disabilities and thus favours marginalization. These situations are not easy and involve superfluous elements such as mercy, compassion or feeling of superiority and, at the same time, are associated with necessary elements, such as sense of symmetrical relations and equality. Therefore, it appears that 
research does not clearly indicate the positions that schools with integrated classes recognize as a place to develop only positive attitudes towards persons with disabilities, as pointed out in previous reports. Other factors are worth mentioning here, which, in addition to the school conditions that are considered to be environment-related, are also relevant for developing these attitudes. These include, to a large extent, in addition to experience and previous contacts with persons with disabilities, inter alia: socio-demographic factors such as age, gender, nationality, financial status, education level, and residence [14]. The latter, namely, the place of residence, is equally interesting as an environmental factor, and is also the place of upbringing and education for children and young people. In research on attitudes towards persons with disabilities, Sękowski [10] assessed the importance of urban and rural environments for the positive attitude. He found that the place of residence is a factor affecting attitudes towards persons with disabilities and reported that people living in an urban environment are more positive about persons with disabilities than those living in a rural environment [15]. However, the author notes that as socio-cultural changes take place, these differences may gradually fade. It appears that societies operating under different cultural or economic conditions, often imposed by cities or countryside $^{1}$, may otherwise determine disability and react differently to it [16]. This phenomenon appears to be the result of differences in cultural paradigms which dictate a specific lifestyle of societies and their individuals [17]. Culture in more developed areas, which are more and more often urban environments, emphasizes heterogeneity (fostering differences), pluralism (giving equal status to different audiences) and individualism (individuals' preference as an autonomous centre of human activity) compared to less developed rural areas, where homogeneity predominates (it seeks to unify society), monism (focusing on one's own social group) and collectivism (it requires that the objectives of the individual be subordinate to those of the group's interest). It therefore appears that in cities that are more developed, disability is considered to be a different category - not of value as lower or higher than non-disability - and therefore persons with disabilities are probably respected and treated equally to other members of this social group. However, in less-developed, rural culture, disability can be considered as non-compliance with group-based standards, and therefore discrimination may occur here. Positive attitudes towards persons with disabilities are more often declared by individualistic groups than collective ones,

${ }^{1}$ In this work, the concept of "village" used interchangeably with "rural area" is defined in terms of the concept of "community", signifying not only a specific area, usually with low population density, dominated by agricultura work, but also a characteristic type of bonds: on a social level, based on relative-neighbour relationship and long-term residence. Rural residents form a community as part of which they have mutual responsibilities and, during a potential crisis, help each other [15]. since behaviour in the former is mainly determined by personal objectives, and, moreover, independence and autonomy are highly valued [18].

These studies on attitudes towards persons with disabilities address the existing state, selected conditions of their development and modification possibilities - for example through schools with integrated classes. The environmental factor, which is probably important in the process of developing attitudes especially in children and young people, is cognitively interesting, as confirmed by Sękowski [10]. In his view, these groups have the greatest opportunities for modifying attitudes towards persons with disabilities and focusing them on more positive ones. Therefore, the authors of this study took a particular interest in attitudes towards persons with disabilities among young people attending urban and rural schools and schools with integrated classes, in order to try to determine - as a result of independent research - how a particular school environment impacts positive attitudes towards persons with disabilities. To evaluate this issue, the following research questions were formulated:

What is the attitude of young people to persons with disabilities according to the variables school type and gender?

Do young people's attitudes towards persons with disabilities differ (and if so, how) according to the variables school type and gender?

\section{MATERIAL AND METHODS \\ SAMPLE}

The survey was conducted among 200 persons aged 14 and 15 attending three selected primary schools: a mainstream rural school $(\mathrm{F}=40, \mathrm{M}=40)$, a mainstream urban school $(\mathrm{F}=30, \mathrm{M}=30)$, and a mainstream urban school with integrated classes $(F=30, M=30)$. The survey was carried out in 2019 among students of schools in Koźminek (mainstream rural school) and Krotoszyn (mainstream urban school, mainstream urban school with integrated classes). Koźminek is located in the Greater Poland Province, in the Kalisz County. The number of inhabitants of Koźminek is 1,800 , while that of the commune of Koźminek is 7,600. There is one primary school in Koźminek attended by about 360 students [19]. With regard to the city, the research was carried out in Krotoszyn. It is a city in the Greater Poland Province, the seat of the Krotoszyn County and the Krotoszyn Commune. According to data from December 31, 2019, the city had 28,804 inhabitants [20]. The study was conducted during educational hours (physical education lesson) in the presence of a tutor and a physical education teacher with the consent of the school management. The respondents were familiarized with the purpose of the study and were given instructions on how to fill in the questionnaire and ensure their anonymity.

\section{RESEARCH TOOL}

The test method used was a diagnostic survey, whereas survey was the technique applied, and the 
research tool was the Scale of Attitudes Towards Persons with Disabilities [Skala Postaw Wobec Osób z Niepełnosprawnością] (PWON) by Sękowski. It is of high reliability - Cronbach's $\alpha=0.82$. The participants responded to the statements contained in the survey using a six-point Likert scale. The tool is based on the assumption that the more similarities in behaviour of persons with disabilities and non-disabled persons can be seen by the respondent, the more positive their attitude is; also the higher the results are in the range 0 to 180 , the more favourable is the attitude towards persons with disabilities. The author, when constructing his own scale, based it on the assumption that positive attitudes towards people with disabilities are characterized by noticing similarities in behaviour, opportunities, preferences and other forms of life, as well as the activity of disabled and non-disabled people, tensions as a result of the discrepancy between the cognitive structures shaped by the image of a healthy person and the real image taking into account the different features of disabled people. The more similarities are noticed in the behaviour of disabled and non-disabled people, the smaller the cognitive dissonance and the more positive the attitude. The PWON scale that was used consisted of 30 questions. The participant responds to each statement depending on their beliefs, and has the choice of one of the following six options for each statement: I definitely agree, I agree, I mostly agree, I mostly disagree, I disagree, I strongly disagree [7].

\section{STATISTICAL ANALYSIS}

Data obtained in the research process were subjected to variance analysis (ANOVA) based on the following formula: 2 (sex: women vs. men) x 3 (type of school: mainstream rural school vs. mainstream urban school vs. mainstream urban school with integrated classes) $\mathrm{x}$ attitudes towards persons with disabilities. As a result of the statistically significant main effect obtained via ANOVA, a post-hoc analysis was performed with the Bonferroni test. The calculations were performed using the Statistica data analysis system. The results obtained for a given dependent variable indicate that the higher the average value is, the greater is the positive attitude of persons with disabilities.

\section{RESULTS}

Thanks to the PWON scale, it was possible to determine the attitudes of young people towards people with disabilities depending on their school environment.

The ANOVA analysis showed a statistically significant effect: $\mathrm{F}(2.198)=148.28 ; p=0.00 ; \eta^{2}=0.59$, which indicates that the average level of positive attitude of persons towards disabled persons varies in respondents according to the type of school they attend. The condition of variance homogeneity was met (Levene's test, $p>0.05$ ). A post-hoc Bonferroni test was performed to verify the statistically significant effect, which also showed statistically significant differences in the compared groups of young people $(p<0.05)$. There were statistically significant differences between all compared groups of young people, out of which the respondents attending the mainstream urban school with integrated classes $(\mathrm{M}=127.67 ; \mathrm{SD}=20.06)$ show the most positive attitude towards persons with disabilities. The group of young people with the least positive attitude towards persons with disabilities is that attending the mainstream rural school $(\mathrm{M}=65.58 ; \mathrm{SD}=24.53)$, while the "middle ground" attitude between the above-mentioned groups is demonstrated by young people from the mainstream urban school $(M=11.0 ; S D=23.14)$. The obtained value of the strength of the effect $\left(\eta^{2}=0.59\right)$ indicates that almost $60 \%$ of the variable attitudes of persons towards people with disabilities is explained by the variable type of school attended by the respondents. This result is considered average (Fig. 1).

Data analysis showed that a more positive attitude towards persons with disabilities is shown by female respondents $(\mathrm{M}=104.81 ; \mathrm{SD}=38.40)$ compared to male respondents $(\mathrm{M}=98.61 ; \mathrm{SD}=34.33)$. ANOVA analysis, however, did not show a statistically insignificant effect $\mathrm{F}(1.198)=3.7174, p=0.06 ; \eta^{2}=0.02$, which indicates that gender is not confirmed as a significant factor which differentiates attitudes of respondents towards persons with disabilities. The obtained value of the strength of the effect $\left(\eta^{2}=0.02\right)$ indicates that $20 \%$ of the variable attitudes of persons towards people with disabilities is explained by the variable gender. This result is described as below average (Fig. 2).

The interaction between the variables gender and school type was not demonstrated in average attitudes towards persons with disabilities, as demonstrated by a two-factor ANOVA analysis of results, which showed a statistically insignificant main effect: $\mathrm{F}(2.198)=1.9012$;

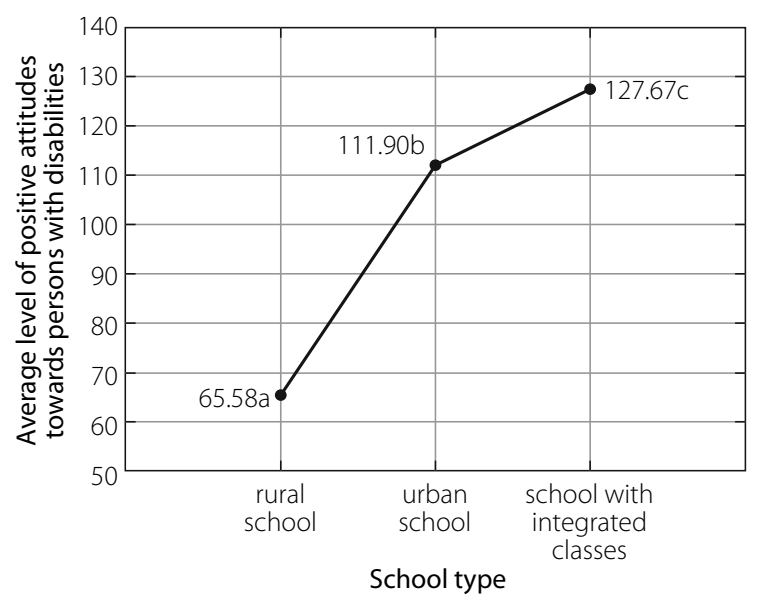

FIGURE 1. Average level of positive attitudes towards persons with disabilities in investigated group of young people depending on variable school type attended by respondent

*Average values that do not have a common letter mark are statistically significantly different (post-hoc analysis - Bonferroni ad hoc test). 


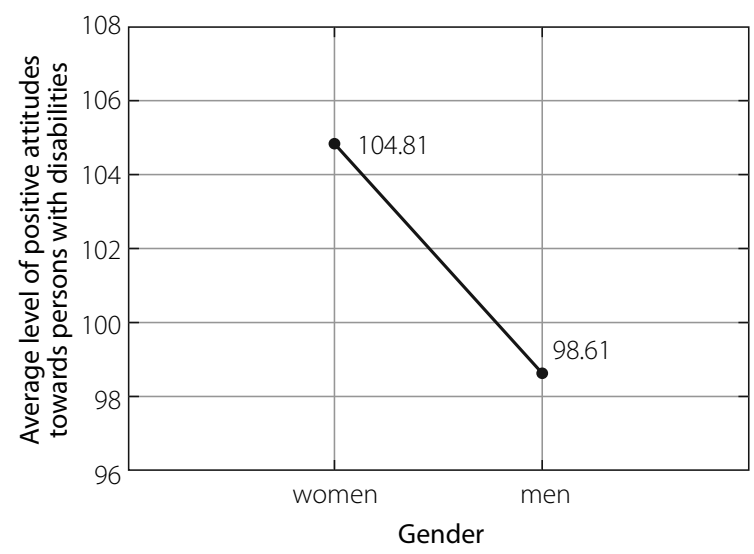

FIGURE 2. Average level of positive attitudes towards persons with disabilities in investigated group of young people depending on the variable gender

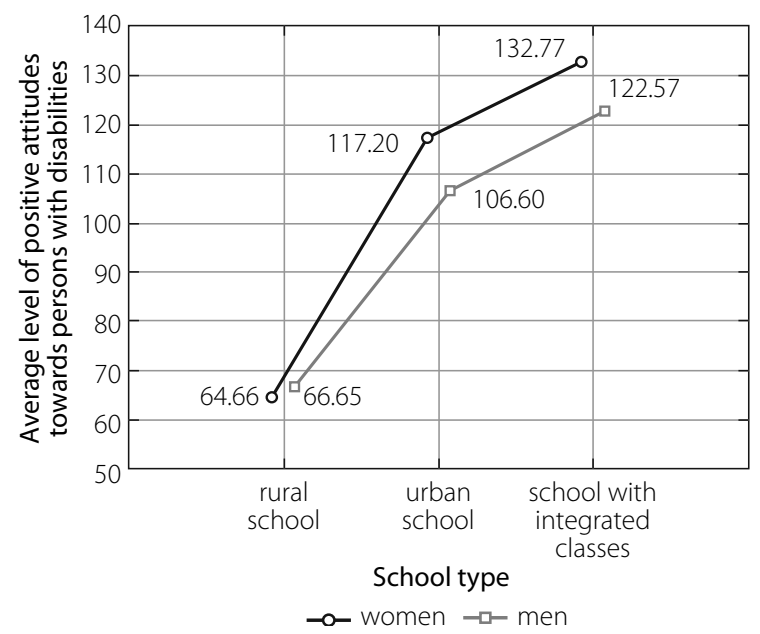

FIGURE 3. Average level of positive attitudes towards persons with disabilities in the investigated group of young people, depending on the variable school type attended by respondents and the variable gender including the school type* gender interaction

$p=0.15 ; \eta^{2}=0.02$ for attitude towards persons with disabilities. The obtained value of the strength of the effect $\left(\eta^{2}=0.02\right)$ indicates that $20 \%$ of the variable attitudes of persons towards people with disabilities is explained by the interaction of the variables school type and gender. This result is described as below average (Fig. 3).

\section{DISCUSSION}

Attitudes towards persons with disabilities are to a large extent a result of the social environment impact and the specific characteristic related to the sphere of feelings, needs and opportunities [21]. In the literature, the general view is that it is a defined hierarchical structure whose elements are in a strict relationship at three levels - macrosystem, mesosystem and microsystem - which reflect the process of developing attitudes towards persons with disabilities to the fullest possible extent [22]. The system of values, set out in a given society, is a macrosystem and consists of e.g. language, religion, historical tradition, customs, and system of values, resulting from intergenerational transmission of culture (stereotypes, prejudice, social attitudes). What follows in the hierarchy is the mesosystem which consists of factors related to the personality and functioning of healthy people: age, gender, education, level of intelligence, authoritarianism, personality traits, anxiety, empathy, occupation, range of contacts with disabled persons and others. The final part is a microsystem within which the factors related to the functioning of a disabled person are mentioned, including inter alia the degree and type of disability, type of disorders suffered, autonomy and independence, and level of communication. The authors of the present work focused their attention mainly on the highest levels mentioned: the macrosystem and the mesosystem with particular emphasis on and analysis of the place of residence (village, city) and opportunities of education in a mainstream school with integrated classes. They observed significant differences with regard to the level of positive attitudes towards persons with disabilities depending on the factors mentioned, which also reflects the current state of literature on the subject.

In their research, Sękowski and Krempa [23] found that when presenting certain attitudes towards persons with disabilities, the occurring intercultural differences are significant, and they are linked to the place of residence and the community that surrounds an individual. The authors noted that people living in Belgium perceive persons with disabilities more negatively than those living in England, Denmark or Portugal. In general terms, however, people from Western Europe are more favourably disposed towards disabilities, and they also have greater awareness and acceptance of social inclusion than those from Asia and Africa. This phenomenon is explained by more frequent contacts with persons with disabilities in schools, experiences resulting from integration and greater knowledge that is not determined by stereotypical or negative beliefs among people living in Western Europe. However, by analysing the local environment and taking into account the division into rural and urban areas, as the authors of this paper did, it appears that this problem was already addressed by other researchers in 1980s. Already at that time there were significant differences in attitudes towards persons with disabilities between rural areas and urban areas. In the rural environment persons with disabilities were seen as those who can threaten society and are unpredictable in their behaviour [21]. However, the more recent research reports more positive attitudes towards persons with disabilities that characterise people living in the city compared to those living in the countryside, although Sękowski and Krempa [23] note that these differences are gradually decreasing as a result of socio-cultural changes. Living in rural areas as a factor 
affecting more negative attitudes towards persons with disabilities was recognized in the research by Ostrowska and Sikorska [24], who enumerate the consequences of such a state for persons with disabilities themselves. The authors claim that these attitudes lead to marginalization of persons with disabilities who are not socially active and - as a result - become increasingly passive, isolated and have status-related disabilities. It appears that holding the status of a rural area resident is among the barriers preventing persons with disabilities from social participation. Marciniak-Madejska [25] as well as the scientists previously mentioned observed the accumulation of phenomena which affect social marginalization of the group in question. The researcher also specifies the types of barriers that directly hinder the process of integrating persons with disabilities with other rural residents. These include socio-economic barriers (demographic structure, professional status, education, financial situation), communication (reducing the functioning in the public space and the use of accessible goods and services), institutional (network of state and non-governmental institutions implementing educational and rehabilitation tasks), and environmental and social ones (family and local communities). These are four key constraints in the organization of everyday life for persons with disabilities in rural areas. For example, good communication between rural areas and urban areas, as mentioned, is particularly significant due to the fact that a large part of institutional support for persons with disabilities is provided in urban areas. Assistance addressed to children with disabilities and their families is granted almost exclusively in poviat [county] towns [26]. NGOs play an important role in social integration of persons with disabilities. However, on a permanent basis, few rural residents undertake to set up an organization that would fill an existing gap in the system of education and social assistance [27]. A lack of similar impulses to develop/organise association-like forms of action or to stimulate the development in overcoming difficult situations which burden the whole local community significantly reduces the integration potential of the rural environment [15]. There is a marked disparity between urban areas and rural areas that results in fewer opportunities for rural residents to develop and integrate [25], which results from the conditions due to the low economic level, long distances and significant difficulties in accessing education, social or cultural infrastructure [28]. Gąciarz et al. [29] found in their research that the specific psychological layer of rural inhabitants may be relevant for negative attitude towards persons with disabilities in the rural area. They called it a syndrome that manifests itself as a sense of helplessness and social apathy, which is often found in contacts with persons with disabilities among rural residents. Due to this attitude of the local community, persons with disabilities withdraw from their lives and close themselves in a narrow world of their home life. The result is their absence in the community they live in. Such a situation is a factor which causes further consequences when such persons appear in public situations and places and then it is perceived as an extraordinary phenomenon which often results in reluctant reactions of the social environment. According to Gąciarz et al. [29], an extreme, but still universal social problem is the fact that in the self-awareness of many people, a child or even an adult with disabilities is a source of shame for their family and should be hidden away; also nobody talks or shares the social environment with such persons.

The picture of negative attitudes towards persons with disabilities has also been confirmed in research by the authors of the present work for young people living and learning in rural areas. The scientists compared this attitude to young people living and studying in an urban area. They found that this group has a more positive attitude to persons with disabilities. These results are also in line with the literature on the subject. It turns out that the impact of neighbourhood in larger urban centres is already changing the awareness of the rural population within attitudes towards persons with disabilities. They are changing its direction to a more positive one, and the presence of persons with disabilities in the public sphere (shops, schools, offices, playground, field, etc.) is no longer strange and disturbing. This creates a basis for a lasting form of attitude which is open to persons with disabilities and understanding of needs associated with disorders characteristic for the group of persons with disabilities. However, it is a contrast for traditional rural municipalities located far away from larger cities [29]. An explanation for more positive attitudes towards persons with disabilities among people living in urban areas may also be the so-called modern personality that this group represents. Under this term sociologists define the type of personality that was induced by processes characteristic for industrial society (industrialization, urbanization, social mobility, mass communication) for which the city is a place of change [30]. The characteristics of the modern personality include such traits as openness to new experiences, readiness to accept diversity, weakening fear of otherness, a future-oriented attitude, increased importance of education, and respect for human dignity. The structures of modern society that to a larger extent include inhabitants of cities have therefore generated a personality that through general attitudes to life makes changes in relation to many issues, but also to those related to health, which contributes to changing of attitudes towards persons with disabilities, as well as changing the attitudes of these people in view of their own limitations and their consequences. Thus it appears that an increasingly established attitude of respect for other humans signifies positively discussed interactions and is a guarantee of their relative sustainability [31]. However, Stępniak and Herdzina [32] identified in 
their research a less positive image of the contemporary society. According to the authors, the current social barriers, which are often caused by the tendency of modern societies to value (especially in large cities), are an important and serious problem. Persons with disabilities are treated as economically unproductive members of society who are additionally a heavy burden on the state budget. Similarly, Kazanowski's research [33] carried out among high school students showed that students from large cities are less tolerant and do not see the task-based usefulness of a peer with disabilities. These results do not correspond to those obtained in the present paper, while Kazanowski [33] found in the analysis of results that women are more prepared to engage constructively in the integration process with persons with disabilities. According to the results of the present work, girls were more favourably disposed towards persons with disabilities regardless of the type of school they attended, but the difference was not statistically significant.

An interesting issue is the possibility of changing attitudes towards persons with disabilities. Wieczorek, Sadziak and Matczak [34] in their research expressed their interest in this problem. The team of researchers found that it was possible to change attitudes in a group that was subject to a pedagogical experiment in a more positive direction. The experiment was conducted through the implementation of the "Join Us" Special Olympics Educational Program. Research showing similar results looks promising primarily for education of young people from rural areas. Similar results were presented in the study by Chimicz [35], who carried out research among children attending grades 1-6 of primary school. Chimicz concluded that properly planned and implemented educational actions aimed at bringing the various aspects of disability to pupils contribute to a more positive attitude. Direct experience is considered to be of particular importance to developing attitudes towards the social environment. This means that by contacting the respondent of their attitude, persons shape their belief about emotional attitude and disposition to behave towards it [36]. The same is true of attitudes towards persons with disabilities. The results presented by Sękowski in his study [7] indicate that people with more frequent contacts with persons with disabilities have more favourable attitudes towards this group. This is also confirmed by the studies $[37,38]$ in which people who study medicine or work with people with disabilities have a more positive attitude towards people with disabilities.

It seems that one of the most effective forms of continuous contact with persons with disabilities, which can contribute to changing attitudes towards persons with disabilities, is schools with integrated classes for children and young people. It is also the third environment that was analysed in the present work. Other research authors, including Sciora [39], also took an interest in this place of education, suspecting that the manner of education, and especially integration training, is a factor that shapes attitudes towards persons with disabilities. The author observed that young people having contact with persons with disabilities during their education as well as those working with this group show positive attitudes towards them. This is in line with the results obtained by the authors of the present study, which showed that pupils in schools with integrated classes have a significantly higher level of positive attitude towards persons with disabilities compared to pupils from mainstream schools. The aim of the integrated education specified above, which includes common teaching and education of non-disabled and disabled children, is to support development of both groups and to build desirable relationships between them based on mutual acceptance and readiness to cooperate. Mutual contacts allow for removal of any fear of sharing the space with persons with disabilities. Also parents of non-disabled children are fully aware that their children can behave naturally in their contacts with disabled peers both in the school environment and during an accidental meeting with such a person [40]. By contacting peers with disabilities healthy children become more friendly, empathic and responsible. Child egocentrism subsides more easily in them and more often they perceive a given situation from different perspectives. Thus they become sensitive to the needs of others - hence the increase in their understanding for other people [41]. As it turns out, living and working with students with disabilities teaches children healthy tolerance, patience and understanding, and gives them an opportunity to expose their social behaviours and to provide help to others. Working, playing and learning together is an opportunity for children attending in schools with integrated classes to learn from each other and to see that each one is different, but also unique [40]. The presented characteristics of the schools with integrated classes explains to a large extent the result obtained by researchers, namely that pupils attending schools with integrated classes are highly positive towards persons with disabilities. Despite studies demonstrating the significant value of schools with integrated classes in developing positive relationships between persons with disabilities and their non-disabled peers, however, the literature on the subject also provides an opinion on the lack of readiness of schools with integrated classes to educate persons with disabilities due to their needs and opportunities (e.g. cognitive). Schools are not fully prepared as a base, both in terms of architecture and suitably qualified specialists $[42,12]$. According to the study by Sadowska and Janiszewska-Nieścioruk [43], students, despite their attempt to be educated in schools with integrated classes, move, over time, to special schools, which, according to the authors, is the place to rebuild a sense of competence and good relations with others as well as a positive image of oneself. The authors of the study find that the con- 
temporary face of implementing the idea of integration is rather apparent and does not induce positive changes only. An overview of various papers thus requires a deeper reflection and mapping of the challenges facing persons responsible for the process of organizing education in which both benefits and potential risks should be carefully analysed, as the statement that the offered form of integrated education is not appropriate for all groups of persons with disabilities [43] is justified. Gore [44] emphasizes in her research that disabled students are still isolated from the general school population despite attending public schools with integrated classes.

However, when presenting different positions in relation to integrated education, it should be mentioned that in the area of developing attitudes towards persons with disabilities, it can contribute to a change towards positive effects in children and young people as demonstrated by the studies presented here. It therefore appears that owing to a properly prepared school environment and involvement of peers, the opportunity to have genuine and planned educational integration, thereby improving the quality of life of children with disabilities and their families, can be more realistic [45]. Such aware education for young people can help to eliminate often unjustified fears, worries or prejudices against people with disabilities that impose upon the most severely disabled people barriers that prevent effective integration, namely mental barriers [35].

\section{CONCLUSIONS}

Due to the limitations of the study, such as the small sample size and the need to survey a larger number of schools of a particular type, the obtained results cannot be generalized and related to the population. Therefore, in this study, the conclusions refer only to the study group and constitute pilot study. On the basis of the results obtained, the following conclusions can be drawn: The type of school attended by the young people in question is significantly related to attitudes towards persons with disabilities. Young people attending a mainstream urban school with integrated classes have a more positive attitude towards persons with disabilities than young people attending mainstream urban and rural schools, which is likely to result from increased contact with persons with disabilities in school conditions. On average, the investigated girls showed a more positive approach towards persons with disabilities than the investigated boys, but the difference was not significant. It appears that the educational process, especially in mainstream schools in rural areas, needs to be complemented by lessons devoted to the problem of disability that will raise awareness among young people and may lead to integration of communities with persons with disabilities.

Research into attitudes towards persons with disabilities among young people should be continued as its results enable monitoring of one of the major indicators of human- ism among young people and identification of school environments that require educational changes aimed at altering the perception of persons with disabilities.

\section{DISCLOSURE}

The authors report no conflict of interest.

\section{REFERENCES}

1. Wójcik J. Lekarz. Zawód czy powołanie? Postawy lekarzy wobec pracy zawodowej [Profession or vocation? Doctors' attitudes towards professional work]. Oficyna Wydawnicza, Katowice 2018. Available from: https://www.researchgate.net/ publication/324705855 (accessed: 7 April 2021).

2. Myers DG. Psychologia społeczna [Social Psychology]. Wydawnictwo Zysk i Spółka, Poznań 2003.

3. Strelau J. Psychologia: podręcznik akademicki. Jednostka w społeczeństwie i elementy psychologii stosowanej [Psychology: an academic textbook. The individual in society and elements of applied psychology]. Wydawnictwo Psychologiczne, Gdańsk 2000.

4. Bokszański Z, Kojder A. Encyklopedia socjologii. Tom 3. [Encyclopedia of Sociology. Volume 3]. Oficyna Naukowa, Warszawa 1998.

5. Gerring RJ, Zimbardo PG. Socjologia i psychologia społeczna. Zarys wykładu [Sociology and social psychology. Outline of the lecture]. Wydawnictwo Wyższej Szkoły Humanistycznej im. Aleksasndra Gieysztora, Pułtusk 2003.

6. Zajdel K. Postawy uczniów klas I-III wobec niepełnosprawności w klasach integracyjnych. Rozważania teoretyczne i praktyczne. Opieka i wychowanie - wybrane zagadnienia [Attitudes of students in grades 1-3 towards disability in integration classes. Theoretical and practical considerations. Care and education - selected issues]. Zeszyty Wydziału Humanistycznego KPSW 2013; 8: 41-62.

7. Sękowski AE. Psychospołeczne determinanty postaw wobec inwalidów [Psychosocial determinants of attitudes towards the disabled]. Wydawnictwo UMCS, Lublin 1994.

8. Domagała-Zysk E. Kształtowanie adekwatnych postaw wobec osób niepełnosprawnych [Shaping adequate attitudes towards people with disabilities]. In: Wychowanie chrześcijańskie. Między tradycją a współczesnością [Christian education. Between tradition and modernity]. Rynio A (ed.). Wydawnictwo KUL, Lublin 2007; 922-931.

9. Bogucka J. Wychowanie i nauczanie integracyjne. Centrum Medyczne Pomocy Psychologiczno-Pedagogicznej MEN, Warszawa 1994.

10. Sekowski A. Tendencje integracyjne a postawy wobec osób niepełnosprawnych [Integration tendencies and attitudes towards disabled people]. In: Pedagogika specjalna w reformowanym ustroju edukacyjnym [Special education in the reformed educational system]. Palak Z (ed.). Wydawnictwo UMCS, Lublin 2001.

11. Kulesza EM. Prospołeczne zachowania wobec rówieśników $z$ niepełnosprawnością w rysunkach pełnosprawnych uczniów pierwszej klasy [Pro-social behavior towards peers with disabilities in the drawings of non-disabled first-grade students]. In: Jest człowiek z niepełnosprawnością - pola refleksji [There is a man with 
a disability - fields for reflection]. Antoszewska A, Myśliwczyk I (ed.). Wydawnictwo Silva Rerum, Poznań 2017; 125-144.

12. Bełza M, Prysak D. Upokorzona codzienność osób niepełnosprawnych [Humiliated everyday life of people with disabilities]. Parezja. Czasopismo Forum Młodych Pedagogów przy Komitecie Nauk Pedagogicznych PAN. Studia i eseje 2/2014 Available from: cejsh.icm.edu.pl/cejsh/element/bwmeta1.element.hdl_11320_2824 (accessed: 7 April 2021).

13. Gajdzica Z. Sytuacje trudne w opinii nauczycieli klas integracyjnych [Difficult situations in the opinion of teachers of integration classes]. Oficyna Wydawnicza Impuls, Kraków 2011.

14. Tervo RC, Azuma S, Palmer G, Redinius P. Medical student's attitudes toward persons with disability: a comparative study. Arch Phys Med Rehabil 2002; 83(11): 1537-1542.

15. Gorlach K. Socjologia obszarów wiejskich. Problemy i perspektywy [Sociology of rural areas. Problems and prospects]. Wydawnictwo Naukowe Scholar, Warszawa 2004.

16. Pauda-Dolińska B. Postawy wobec osób z niepełnosprawnością: na podstawie opinii polskich i holenderskich studentów [Attitudes towards people with disabilities: based on the opinions of Polish and Dutch students]. Przegląd naukowo-metodyczny. „Edukacja dla Bezpieczeństwa” 2012; 4(17): 129-143.

17. Sieradzki M. Niepełnosprawni w społeczeństwie i kulturze. Wybrane zagadnienia $\mathrm{z}$ socjologii niepełnosprawności i rehabilitacji [Disabled people in society and culture. Selected issues from the sociology of disability and rehabilitation]. In: Społeczeństwo wobec autonomii osób niepełnosprawnych [Society and the autonomy of people with disabilities]. Dykcik E (ed.). Eruditus, Poznań 1996; 87-95

18. Kossewska J. Społeczeństwo wobec osób niepełnosprawnych postawy i ich determinanty [Society towards disabled people - attitudes and their determinants]. Annales Academiae Pedagogicae Cracoviensis. Studia Psychologica 2003; 14: 40-57.

19. Polska w liczbach [Poland in numbers]. Available from: https:// www.polskawliczbach.pl/Kozminek (accessed: 7 April 2021).

20. Polska w liczbach [Poland in numbers]. Available from: https:// www.polskawliczbach.pl/Krotoszyn (accessed: 7 April 2021).

21. Jankowska M. Osobowościowe i społeczno-kulturowe uwarunkowania postaw wobec osób niepełnosprawnych. Badania młodzieży trzecich klas gimnazjalnych [Personality and sociocultural determinants of attitudes towards disabled people. Research on young people from third grades of lower secondary school]. Kwart Nauk 2015; 4(24): 201-227.

22. Kossewska J. Uwarunkowania postaw wobec inwalidów [Determinants of attitudes towards disabled people]. Prz Psychol 2000; 19: 71-84.

23. Sękowski AE, Krempa M. Osobowe i środowiskowe uwarunkowania postaw wobec osób niepełnosprawnych [Personal and environmental determinants of attitudes towards disabled people]. In: Oblicza psychologii klinicznej [Faces of clinical psychology]. Zasępa E, Gałkowski T (ed.). Gdańskie Wydawnictwo Psychologiczne, Sopot 2014; 191-204.

24. Ostrowska A, Sikorska J. Syndrom niepełnosprawności w Polsce. Bariery integracji [Disability syndrome in Poland. Integration barriers]. IFiS PAN, Warszawa 1996.
25. Marciniak-Madejska N. Osoby z niepełnosprawnością na wsi - bariery integracji społecznej [People with disabilities in the countryside - barriers to social integration]. Interdyscyplinarne Konteksty Pedagogiki Specjalnej 2014; 5: 51-67.

26. Niemiec I. Wzajemna percepcja roli i sposobu jej pełnienia a poczucie szczęścia i zadowolenia z małżeństwa rodziców dziecka niepełnosprawnego [Mutual perception of the role and the way of fulfilling it and the sense of happiness and satisfaction with the marriage of parents of a disabled child]. Wydawnictwo Uniwersytetu Śląskiego, Katowice 2006.

27. Trzepałko R, Malecka K. Bariery w zakładaniu organizacji pozarządowych na wsi i małych miastach [Barriers to establishing NGOs in rural areas and small towns]. Fundacja Wspomagania Wsi, Warszawa 2011.

28. Krause A. Normalizacja życia osób niepełnosprawnych jako podłoże relacji i doświadczeń społecznych osób z niepełnosprawnością intelektualną [Normalization of the life of people with disabilities as a basis for relations and social experiences of people with intellectual disabilities]. Wydawnictwo Edukacyjne Akapit, Toruń 2010.

29. Gąciarz B, Ostrowska A, Pańków W. Integracja społeczna i aktywizacja zawodowa osób niepełnosprawnych zamieszkałych w miastach i na terenach wiejskich uwarunkowania sukcesów i niepowodzeń [Social integration and professional activation of people with disabilities living in cities and rural areas, determinants of success and failure]. Raport z badań. IFiS PAN, Warszawa 2008

30. Chodkowska M. Kobieta niepełnosprawna. Socjopedagogiczne problemy postaw [Disabled woman. Socio-pedagogical problems of attitudes]. Wydawnictwo UMCS, Lublin 1993.

31. Sztompka P. Socjologia zmian społecznych [Sociology of social changes]. Wydawnictwo Znak, Kraków 2005.

32. Stępniak I, Herdzian M. Wydatkowanie środków ZEFRON na indywidualne programy rehabilitacji [ZEFRON spending on individual rehabilitation programs]. Wydawnictwo OBPON, Przemyśl 2008.

33. Kazanowski Z. Demograficzne uwarunkowania gotowości młodzieży do integracji szkolnej z rówieśnikami z niepełnosprawnością [Demographic determinants of young people's readiness for school integration with peers with disabilities]. Edukacja - Technika - Informatyka 2018; 1: 231-236.

34. Wieczorek M, Sadziak A, Matczak D. Attitudes towards persons with intellectual disabilities in adolescents. J Educ Health Sport 2019; 9(1): 106-123.

35. Chimicz D. Postrzeganie osób z niepełnosprawnością przez uczniów szkoły podstawowej. Przemiany w rezultacie oddziaływań edukacyjnych [Perception of people with disabilities by primary school students. Changes as a result of educational influences]. Lubelski Rocznik Pedagogiczny 2017; 36(2): 149-169.

36. Wolska-Zogata I. Postawy wobec osób niepełnosprawnych przegląda badań [Attitudes towards people with disabilities reviews research]. Współcz Pielęg Ochr Zdr 2012; 1: 81-86.

37. Kritsotakis G, Galanis P, Papastefanakis E, et al. Attitudes towards people with physical or intellectual disabilities among nursing, social work and medical students. J Clin Nurs 2017; 26(23-24): 4951-4963 
38. Klooster P, Dannenberg JW, Taal E, Burger G, Rasker J. Attitudes towards people with physical or intellectual disabilities: nursing students and non-nursing peers. J Adv Nurs 2009; 65(12): 2562-2573

39. Scior K. Public awarebsess attutudesand beliefs regarding intellectualdisability. A sytsematic review. Res Dev Disabil 2011; 32(6): 2164-2182

40. Maciarz A. Z teorii i badań społecznej integracji dzieci niepełnosprawnych [From the theory and research of social integration of disabled children]. Wydawnictwo IMPULS, Kraków 1999.

41. Chodkowska M. Razem damy sobie radę! W drodze do zintegrowanego społeczeństwa [We'll be fine together! On the way to an integrated society]. Wydawnictwo Szkolne i Pedagogiczne, Warszawa 2009.

42. Sakowicz-Boboryko A. Edukacja integracyjna jako szansa dla wszystkich - założenia a rzeczywistość [Integration education as an opportunity for everyone - assumptions and reality]. In: Edukacja dziecka - mity i fakty [Child education - myths and facts]. Jaszczyszyn E, Szada J (ed.). Trans Human Wydawnictwo Uniwersyteckie, Białystok 2010; 585-593.

43. Sadowska S, Janiszewska-Nieścioruk Z. O dobrodziejstwie starej, dobrej szkoły specjalnej w perspektywie realizacji obowiązku szkolnego przez uczniów niepełnosprawnych - napięcia między ideą integracji a rzeczywistością [On the benefit of a good old special school in the perspective of fulfilling compulsory education by disabled students - the tensions between the idea of integration and reality]. Przegląd Badań Edukacyjnych 2015; 2(21): 137-152.

44. Gore K. Attitudes between students with disabilities and typically developing students. Theses, dissertations and capstones 2015. Available from: https://mds.marshall.edu/cgi/viewcontent.cgi? (accessed: 7 April 2021).

45. Głodkowska J. W poszukiwaniu modelu edukacji włączającej [In search of an inclusive education model]. Meritum 2009; 2: 5-8.

\section{AUTHORS' CONTRIBUTIONS}

DM i MW prepared the concept of the article. AS analysed data and prepared the first draft of the article. All authors contributed to the final version of the publication and approved the final manuscript. 